\title{
Influence of Eurasian snow cover in spring on the Indian Ocean Dipole
}

\author{
Hongxi Pang ${ }^{1, *}$, Yuanqing $\mathrm{He}^{1,2}$, Aigang $\mathrm{Lu}^{1}$, Jingdong $\mathrm{Zhao}^{1}$, Bo Song ${ }^{1}$, \\ Baoying Ning ${ }^{1}$, Lingling Yuan ${ }^{1}$ \\ ${ }^{1}$ Cold and Arid Regions Environmental and Engineering Research Institute, Chinese Academy of Sciences, \\ Lanzhou 730000, PR China \\ ${ }^{2}$ Institute of Tibetan Plateau Research, Chinese Academy of Sciences, Beijing 100029, PR China
}

\begin{abstract}
The Indian Ocean Dipole (IOD) shows a significant negative correlation with the extent of Eurasian snow cover in spring. The anomalies in the land-sea temperature contrast, which are induced by the anomalies of Eurasian snow cover in spring, reverse the patterns of convection activity anomalies over the western and eastern tropical Indian Ocean in summer. Moreover, for heavier and lighter than normal Eurasian snow cover in spring, anomalies in the vertical zonal circulation over the tropical Indian Ocean (Walker circulation) and in the vertical meridional circulation between the Indian Ocean and the Eurasian continent (Hadley circulation) occur in summer. The Walker and Hadley circulation anomalies probably play an important role in the occurrence and duration of IOD events. Eurasian snow cover in spring is presumably one of the factors that trigger IOD events. These results provide a basis for further investigation of the mechanisms linking snow cover, the Indian monsoon, atmospheric circulation, and sea surface temperature.
\end{abstract}

KEY WORDS: Eurasian snow cover · Indian Ocean Dipole · Ocean-atmosphere coupling • Atmospheric circulation anomalies

\section{INTRODUCTION}

Snow cover is an important component of the terrestrial surface and plays a role in the formation of climate. The effects of snow cover on climate have been studied by Parthasarathy \& Yang (1995), Li \& Yanai (1996), Clark et al. (1999), Bamzai \& Marx (2000), and Chen \& Wu (2000). Higher albedo, lower thermal conductivity and absorption of much latent heat energy when the snow melts result in cooling of the continental climate and produce a significant impact on atmospheric circulation, during and after the period of snow cover (Zhang et al. 2003). The albedo effect is dominant in spring at low latitudes, especially on the Tibetan Plateau, whereas the effect of snow melting is important at mid-latitudes (Yasunari et al. 1991). Although maximum snow cover occurs in winter, the degenerative feedback of snow cover on the radiation balance is greatest in spring, and cooling effects can retard the shift from one season to the next (Groisman et al. 1994a).

Snow cover in Eurasia occurs mainly in the areas of the former Soviet Union and in China. Deep snow cover occurs in northern Eurasia (40 to $120^{\circ} \mathrm{E}, 50$ to $70^{\circ} \mathrm{N}$ ) and on the Tibetan Plateau (Fig. 1). The annual cycle of Eurasian snow cover extent is characterized by a gradual accumulation of continental snow from October to March and a rapid ablation of the snow during spring and summer. Snow is absent from most of the Eurasian region in June to September. The maximum variation of Eurasian snow cover occurs in spring (March and April). The impacts of Eurasian snow cover on climate have been investigated by Hahn \& Shukla (1976), Barnett et al. (1988, 1989), Vernekar et al. (1995), Kripalani \& Kulkarni (1999), and Cohen \& Entekhabi (2001).

By analyzing sea surface temperature anomaly (SSTA) in the Indian Ocean, a dipole oscillation (Indian 


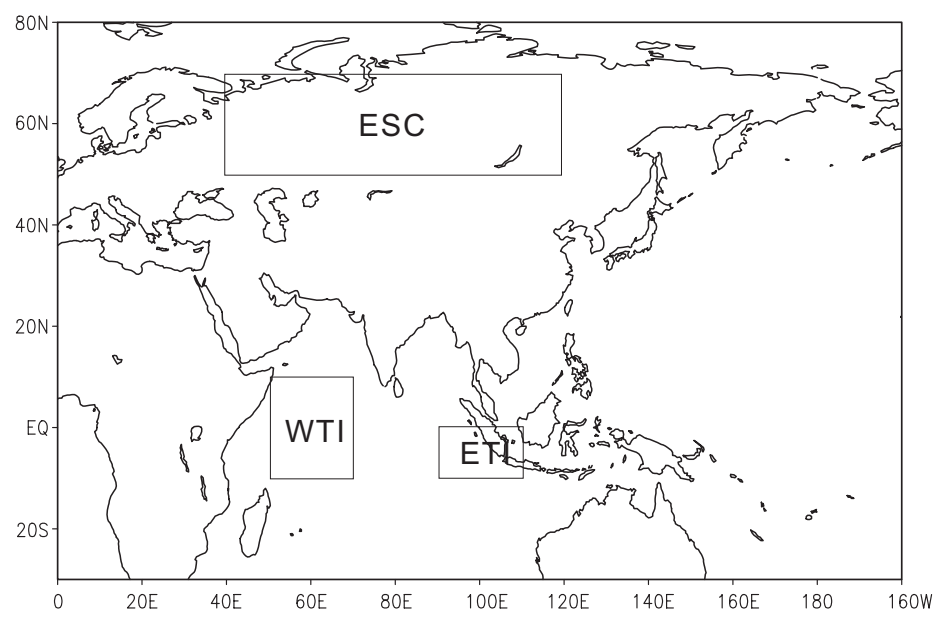

Fig. 1. Eurasian snow cover region $\left(\mathrm{ESC} ; 40\right.$ to $120^{\circ} \mathrm{E}, 50$ to $70^{\circ} \mathrm{N}$ ) and Indian Ocean region. WTI: western tropical Indian Ocean $\left(50\right.$ to $70^{\circ} \mathrm{E}, 10^{\circ} \mathrm{S}$ to $\left.10^{\circ} \mathrm{N}\right)$; ETI: eastern tropical Indian Ocean $\left(90\right.$ to $110^{\circ} \mathrm{E}, 10^{\circ} \mathrm{S}$ to equator). The Indian Ocean Dipole (IOD) index is defined as the difference in sea surface temperature anomalies (SSTA) between WTI and ETI

Ocean Dipole, IOD) was first found by Saji et al. (1999). They defined an index of the IOD as the difference in SSTA between the western tropical Indian Ocean (WTI; 50 to $70^{\circ} \mathrm{E}, 10^{\circ} \mathrm{S}$ to $10^{\circ} \mathrm{N}$ ) and the eastern tropical Indian Ocean (ETI; 90 to $110^{\circ} \mathrm{E}, 10^{\circ} \mathrm{S}$ to the equator). The IOD has 2 patterns: a positive phase (higher SST in the WTI) and a negative phase (higher SST in the ETI). A positive IOD phase leads to drought over the Indonesian region, and to heavy rain and flooding in East Africa, whereas a negative IOD leads to rain and flooding in Indonesia, and to drought in East Africa (Ashok et al. 2001). The IOD is one of the major ocean-atmosphere coupling phenomena in the tropi-

Table 1. Correlation coefficients between the monthly mean index of the Indian Ocean Dipole (IOD) and the extent of Eurasian snow cover in spring. Significance levels: ${ }^{*} p=0.1$;

$$
{ }^{* *} \mathrm{p}=0.05
$$

\begin{tabular}{llll|} 
IOD index & \multicolumn{3}{c}{ Eurasian snow cover } \\
& March & April & Spring mean \\
\hline January & -0.115 & -0.145 & -0.139 \\
February & -0.082 & -0.128 & -0.112 \\
March & -0.057 & -0.118 & -0.094 \\
April & -0.079 & -0.168 & -0.133 \\
May & -0.142 & $-0.267^{*}$ & -0.219 \\
June & -0.199 & $-0.323^{* *}$ & $-0.281^{*}$ \\
July & $-0.268^{*}$ & $-0.377^{* *}$ & $-0.348^{* *}$ \\
August & $-0.299^{*}$ & $-0.379^{* *}$ & $-0.366^{* *}$ \\
September & $-0.319^{* *}$ & $-0.395^{* *}$ & $-0.386^{* *}$ \\
October & $-0.324^{* *}$ & $-0.385^{* *}$ & $-0.384^{* *}$ \\
November & $-0.304^{* *}$ & $-0.393^{* *}$ & $-0.376^{* *}$ \\
December & $-0.277^{*}$ & $-0.388^{* *}$ & $-0.359^{* *}$ \\
\hline
\end{tabular}

cal Indian Ocean; it was originally thought to be unrelated to ENSO (Saji et al. 1999, Webster et al. 1999). Li \& Mu (2001) found that the South Asia High and the Subtropical High in the western Pacific Ocean can be influenced significantly by IOD events. The IOD also has a significant influence on the Indian monsoon and Australian winter rainfall (Ashok et al. 2001, 2003).

Correlations between ENSO and snow cover have been reported by Li (1989), Barnett et al. (1989), and Yang (1993). Based on the model experiments, Barnett et al. (1989) demonstrated that Eurasian snow cover can trigger ENSO events. The present study is the first analysis of the links between Eurasian snow cover and the IOD.

\section{DATA}

Monthly mean IOD index data were provided by $\mathrm{N}$. H. Saji (pers. comm.) for March 1958 to October 1999; Eurasian snow cover extent data in spring (March and April) are available from the USA National Snow and Ice Data Center (NSIDC), reconstructed by Brown (2000) utilizing the reconstructed daily snow depth and NOAA satellite data. In addition, the NCEP/NCAR reanalysis data, monthly mean outgoing longwave radiation (OLR) and wind fields, as well as monthly long-term mean zonal heat flux with $2.5 \times 2.5^{\circ}$ resolution, were obtained from the NOAA-CIRES Climate Diagnostics Center (available at www.cdc.noaa.gov).

\section{RESULTS}

The Eurasian snow cover extent in spring (March, April, and the average of March and April) correlates negatively with the monthly mean IOD index from June to December; the correlation is more significant during September to November (Table 1, Fig. 2), corresponding to the stronger intensity of IOD events in autumn (Li et al. 2002).

In summer, the Tibetan Plateau is a heat source for Eurasia. In years with strong Eurasian snow cover, the intensity of the Tibetan Plateau heat source weakens because of the greater quantity of shortwave radiation reflected in spring (due to the higher albedo), the absorption of much heat in summer (due to the melting of the snow), and the decrease in latent heat release (due to the decrease in summer monsoon rainfall). Inversely, the intensity of the Tibetan Plateau heat source strengthens when Eurasian snow cover is light. Therefore, the land-sea temperature contrast between Eurasia and Indian Ocean is significantly influenced in the summer by Eurasian snow cover anomalies (Barnett et al. 1989). This may affect heat transmission and 


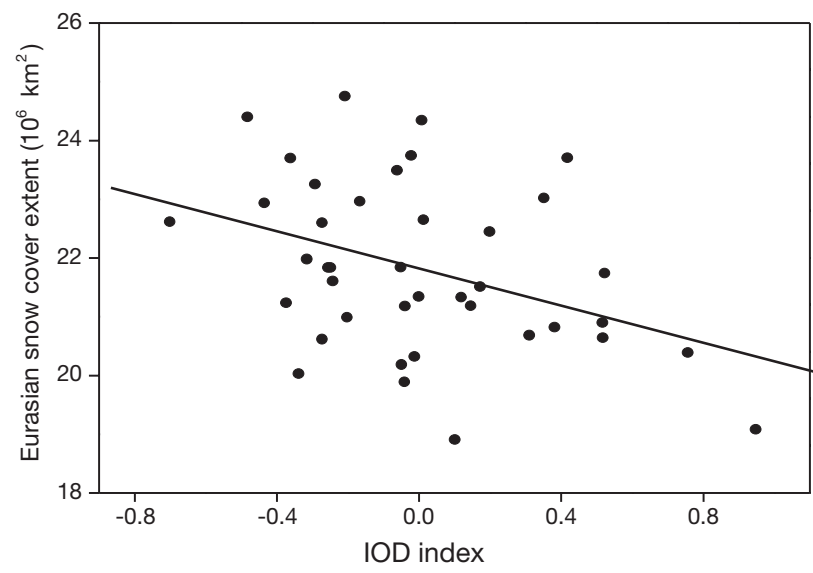

Fig. 2. Scatterplot between the Indian Ocean Dipole (IOD) index (mean from September to November) and Eurasian snow cover extent (mean of March and April). $\mathrm{R}=-0.386$ (significant at $\mathrm{p}=0.01$ )

atmospheric circulation between the Indian Ocean and Eurasia, and between the western and eastern Indian Ocean (Groisman et al. 1994b). Therefore, we analyzed the anomalies of heat transmission and atmosphere circulation patterns in summer (July) to investigate the influence of Eurasian snow cover in spring on IOD events.

In order to define years with heavier and lighter snow cover, the average extent of snow cover in March and April was standardized by subtracting the mean and dividing by the standard deviation (SD). A year with a value $>1.0 \mathrm{SD}$ was defined as a year with heavy snow cover. Inversely, a value <-1 SD was defined as light snow cover. Based on this division, there were 7 yr with heavy snow cover $(1964,1969,1979,1980$, 1981, 1985, 1987) and 6 yr with light snow cover (1962, 1989, 1990, 1992, 1993, 1997). Composite analyses of OLR and wind fields over the Indian Ocean, in years with heavy and light Eurasian snow cover, were used to study the impacts of snow cover in spring on IOD events.

OLR data were lacking before June 1974, which leaves $5 \mathrm{yr}$ of heavy, and $5 \mathrm{yr}$ of light snow cover for analysis. Fig. 3 shows the difference in Indian Ocean OLR in July between years with heavy and light Eurasian snow cover. The distribution pattern suggests that in years with heavy snow cover, convection activity is stronger over the ETI and weaker over the WTI, and vice versa in years with light snow cover. Convection activity is correlated to the temperature in the low troposphere; therefore, when Eurasian snow cover is strong, SST is higher in the ETI and lower in the WTI, which corresponds to the negative phase of an IOD event. The inverse applies in years with light snow cover.

Fig. 4 shows the difference in tropospheric wind vectors in July between years with heavy and lighter snow cover. In the lower troposphere (Fig. 4a), a westerly anomaly occurs over the central tropical Indian Ocean,

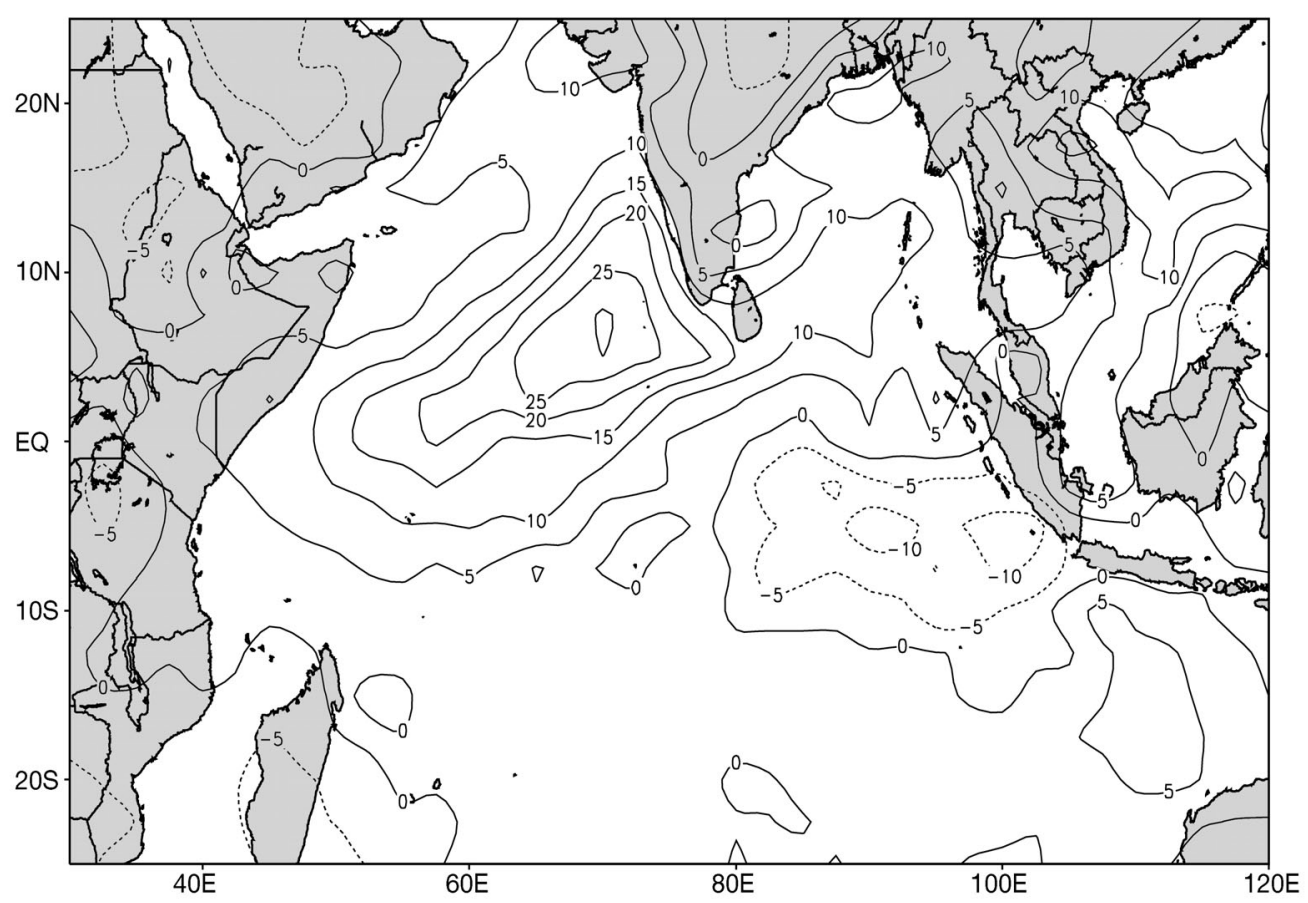

Fig. 3. Difference of outgoing longwave radiation (OLR) in July between years with heavy and light Eurasian snow cover (heavy - light) 
a northerly anomaly over the Bay of Bengal, and a northwesterly anomaly occurs west of Sumatra. There is a reverse circulation pattern in upper of troposphere (Fig. 4b), indicating that the vertical meridional circulation in summer (Hadley circulation) between the Indian Ocean and Eurasia weakens and the vertical zonal circulation (Walker circulation) between the WTI and ETI also weakens in years with heavy Eurasian snow cover, and vice versa in years with light snow cover. The vertical zonal circulation anomalies over the tropical Indian Ocean and the meridional circulation anomalies between the Indian Ocean and Eurasia lead to and maintain inverse SST distributions between the WTI and ETI.

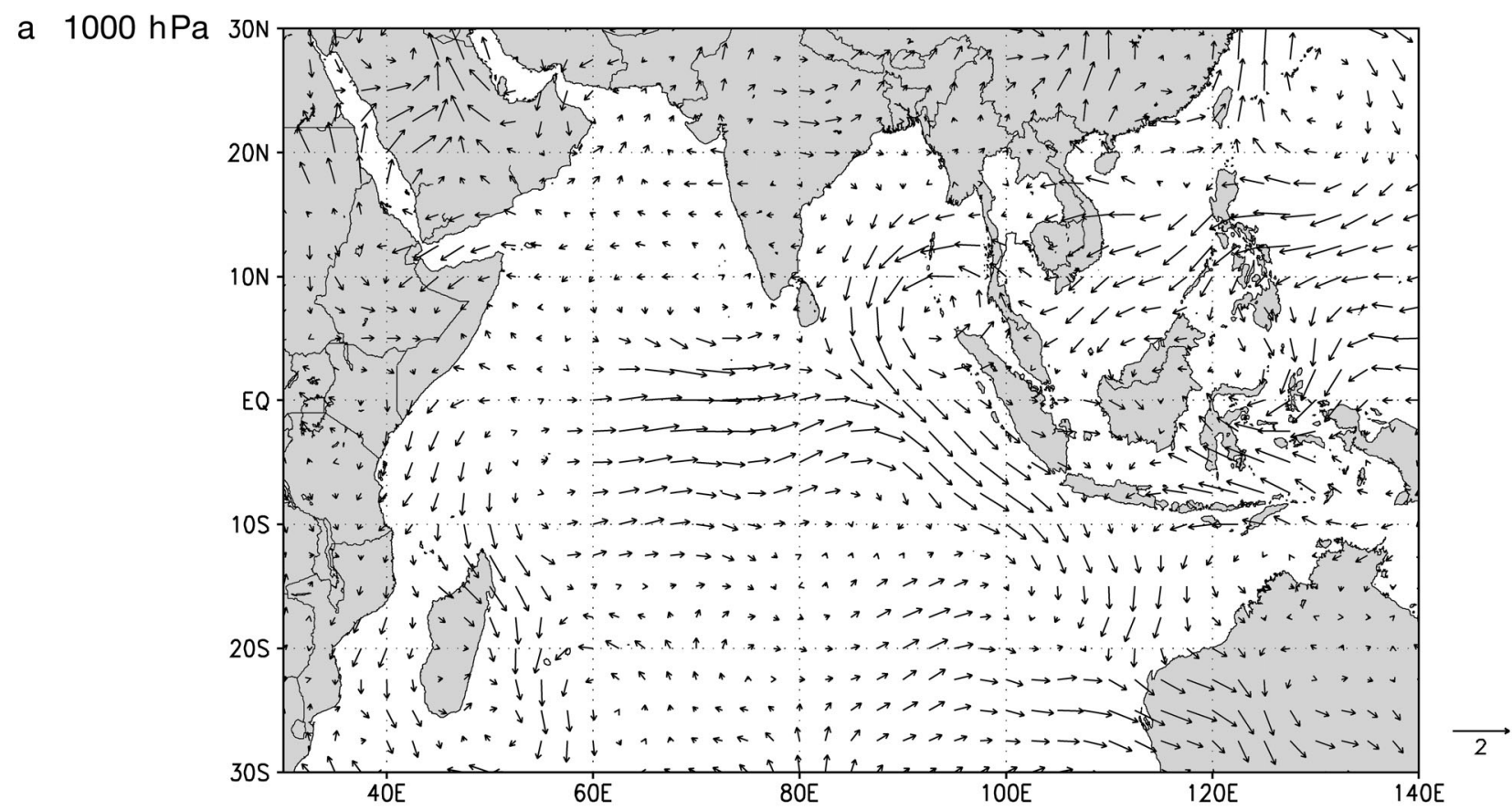

\section{b $200 \mathrm{hPa}$}

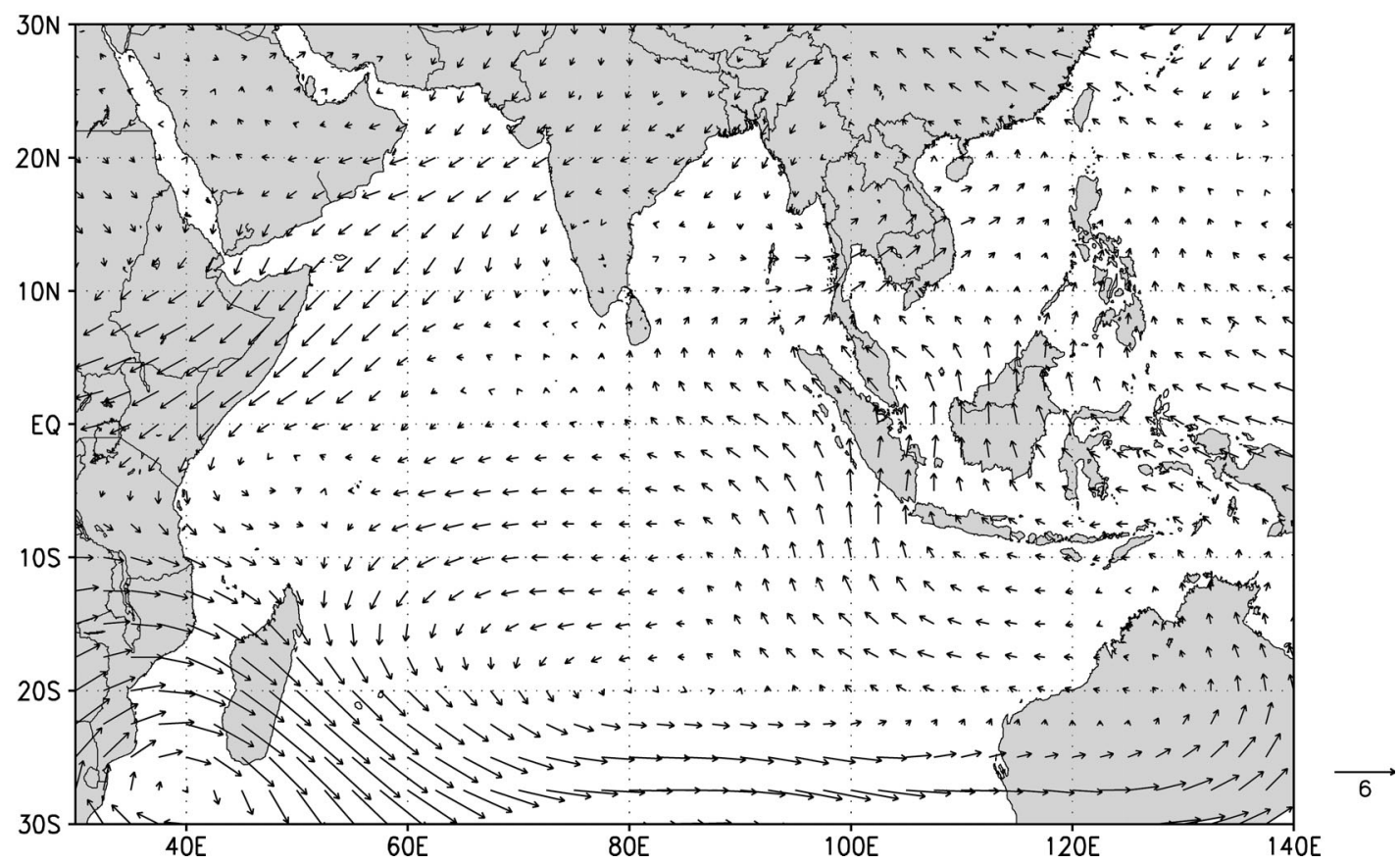

Fig. 4. Difference of wind vectors (arrows) in July in the (a) lower troposphere and (b) upper troposphere between years with heavy and light Eurasian snow cover (heavy - light). Wind vector speed is measured in $\mathrm{m} \mathrm{s}^{-1}$ 


\section{DISCUSSION}

IOD varies with a periodicity of 4 to $5 \mathrm{yr}$ ( Li \& Mu 2001), which is consistent with fluctuations of Eurasian snow cover (Yang 1997). Furthermore, the IOD index was weaker in the 1980s and stronger in the 1990s (Yin et al. 2001), probably responding to higher Eurasian snow cover extent in the 1980s and lower cover in the 1990s (Gao et al. 2003).

Monthly long-term mean zonal heat flux variations in July over the Indian Ocean along the equator show that heat is transmitted westwards in the lower troposphere (Fig. 5a) and eastwards in the upper troposphere (Fig. 5b); this is consistent with the zonal wind circulation (Fig. 4) caused by anomalies of Eurasian

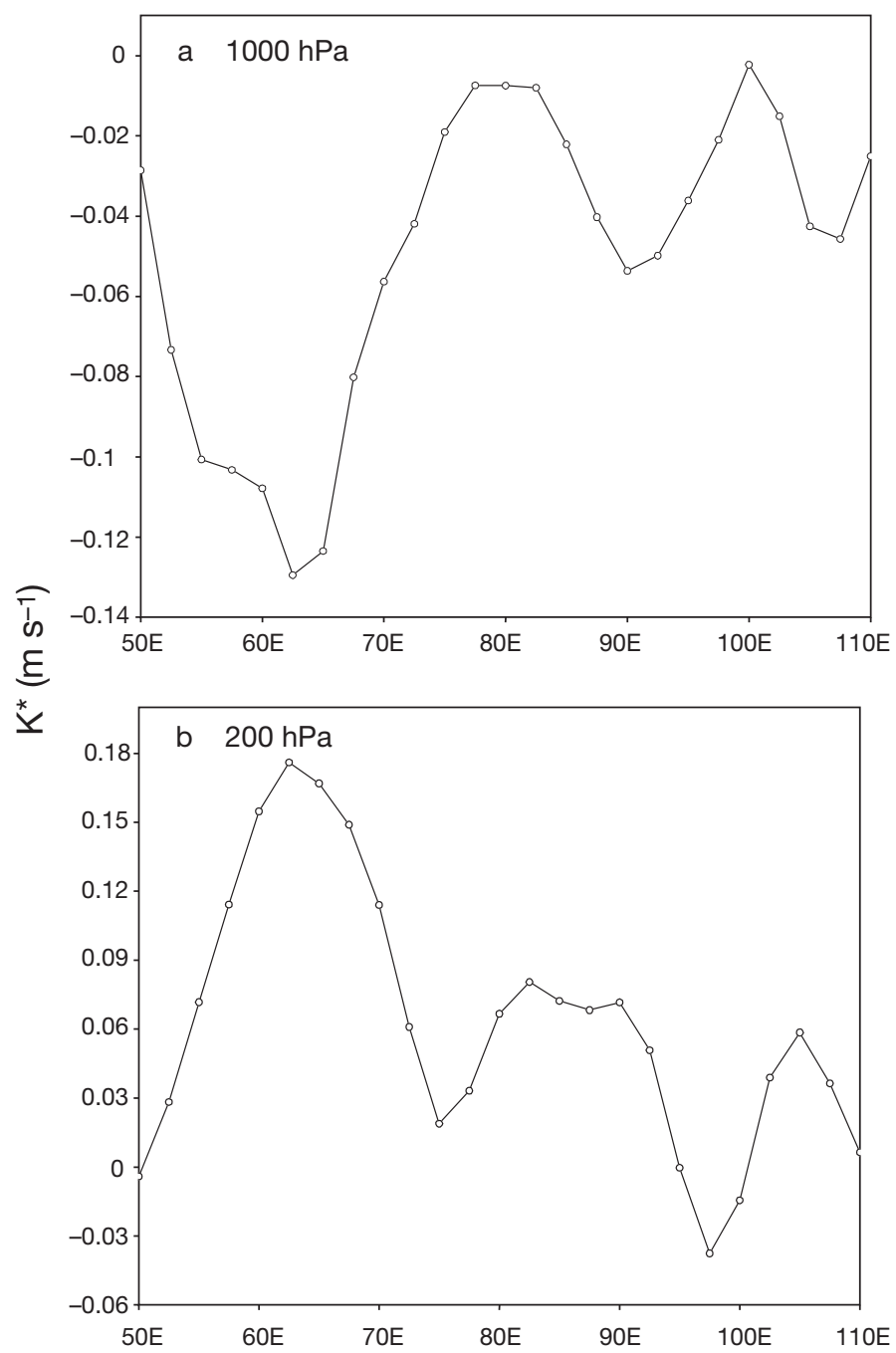

Fig. 5. Monthly long-term mean of zonal heat flux variations in July in the (a) lower troposphere $(1000 \mathrm{hPa})$ and (b) upper troposphere $(200 \mathrm{hPa})$ along the equator over the Indian Ocean snow cover in spring. Therefore, zonal heat transmission over the tropical Indian Ocean is also probably affected by anomalies of Eurasian snow cover, leading to heat redistribution between the WTI and ETI. Snow cover extent could indicate large-scale changes in temperature advection, and the cold, dense air generated above a snow surface may be propagated to far away regions by atmospheric teleconnections (Cohen 1994). Thus, Eurasian snow cover in spring and IOD events may be linked by the zonal heat transmission between the WTI and ETI. Moreover, snow melting, soil moisture and evaporation processes in summer influence soil hydrology and modify the meridional gradient of temperature between the land and the overlying atmosphere, and this also leads to anomalous meridional heat transmission between Eurasia and the Indian Ocean. The possible influence of Eurasian snow cover on IOD events is illustrated in Fig. 6. However, the IOD index is closely linked to the seasonal cycle (Saji et al. 1999), which may not be caused by the Eurasian snow cover. Eurasian snow cover in spring may be a triggering factor for IOD

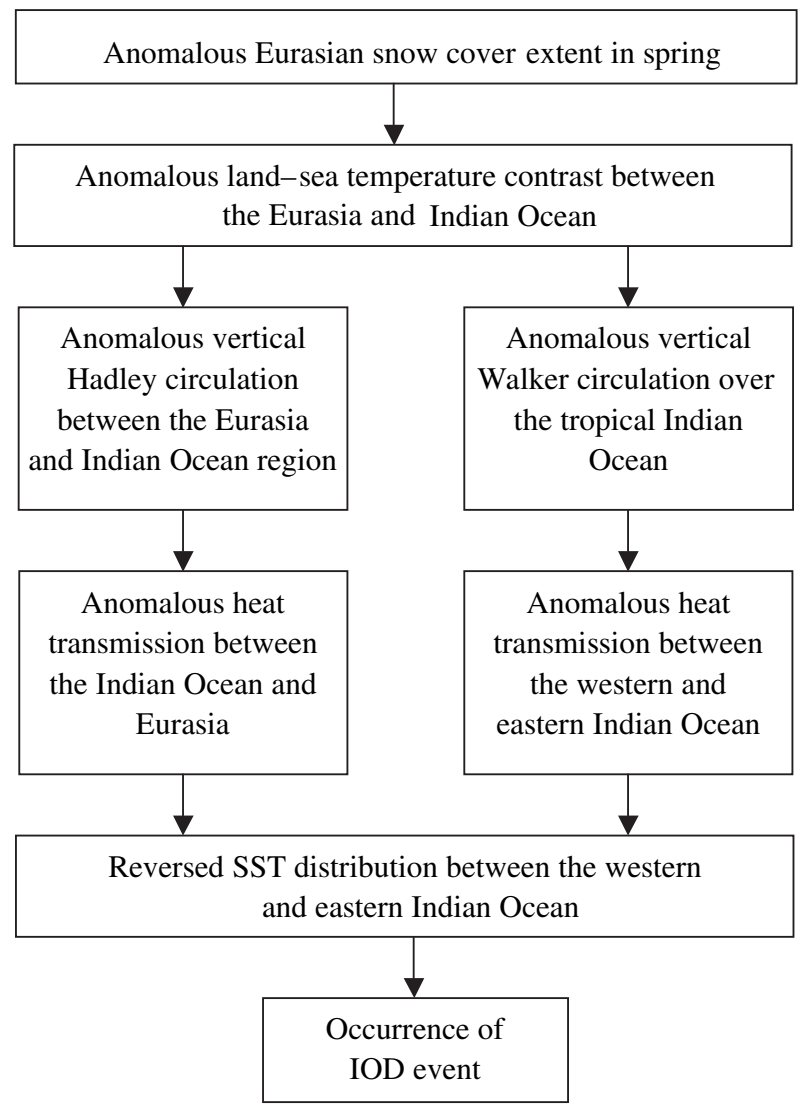

Fig. 6. Possible influence of Eurasian snow cover in spring on the Indian Ocean Dipole (IOD) events. SST: sea surface temperature 
events, and may serve to predict the occurrence and intensity of IOD events.

Temperatures in the Northern Hemisphere have increased by $0.4^{\circ} \mathrm{C}$ between the $1960 \mathrm{~s}$ and the $1980 \mathrm{~s}$, and by about $1.0^{\circ} \mathrm{C}$ from 1990 to 2000 (IPCC 2001). Chapman \& Walsh (1993) and Serreze et al. (2000) found that the strongest warming has occurred during winter and spring. Eurasian snow cover in spring must thus decline. Annual snow cover has been declining since the 1980s (Groisman et al. 1994a), and low cover anomalies have been observed after 1988 (Leathers \& Robinson 1993). Therefore, the change in Eurasian snow cover in spring under the global warming probably influences IOD events significantly. According to the negative relationship between the Eurasian snow cover extent and IOD index, the intensity of positive IOD events can be expected to strengthen, and for negative IOD events it will weaken. Therefore, further investigation of the variations in Eurasian snow cover and IOD events and their influences on climate under the global warming are warranted.

\section{CONCLUSIONS}

The anomalies of Eurasian snow cover in spring probably influence the vertical zonal circulation (Walker circulation) over the tropical Indian Ocean and the vertical meridional circulation (Hadley circulation) between the Indian Ocean and Eurasia. The anomalies of the Walker and Hadley circulations may affect the zonal heat transmission and heat redistribution between the WTI and ETI. Eurasian snow cover in spring is negatively correlated with IOD events, and Eurasian snow cover can probably trigger IOD events.

Acknowledgements. We thank Dr. N. H. Saji (Institute for Global Change Research, Kanazawa, Japan) for providing the IOD data. This study was supported by the Chinese National Natural Science Foundation (grants 90302006, 40501014, 90511007), funds from National Basic Research Program of China (2005CB422003), and the Project for Outstanding Young Scientists (40121101) of the Chinese Natural Science Foundation. Thanks also to Dr. Madhav Khandekar and the editorial staff.

\section{LITERATURE CITED}

Ashok K, Guan Z, Yamagata T (2001) Impact of the Indian Ocean Dipole on the relationship between the Indian Monsoon Rainfall and ENSO. Geophys Res Lett 28(23): 4499-4502

Ashok K, Guan Z, Yamagata T (2003) Influence of the Indian Ocean Dipole on the Australian winter rainfall. Geophys Res Lett 30:1821 (doi: 10.1029/2003GL017926)

Bamzai AS, Marx L (2000) COLA AGCM simulation of the effect of anomalous spring snow over Eurasia on the
Indian summer monsoon. Q J R Meteorol Soc 126: $2575-2584$

Barnett TP, Dumenil L, Schlese U, Roeckner E (1988) The effect of Eurasian snow cover on global climate. Science 239:504-507

Barnett TP, Dumenil L, Schlese U, Roeckner E, Latif M (1989) The effect of Eurasian snow cover on regional and global climate variations. J Atmos Sci 46(5):661-685

Brown RD (2000) Northern Hemisphere snow cover variability and change, 1915-97. J Clim 13:2339-2355

Chapman W, Walsh J (1993) Recent variations of sea ice and air temperature in high latitudes. Bull Am Meteorol Soc 74:33-47

Chen L, Wu R (2000) Interannual and decadal variations of snow cover over Qinghai-Xizang Plateau and their relationships to summer monsoon rainfall in China. Adv Atmos Sci 17:18-30

Clark MP, Serreze MC, Robinson DA (1999) Atmospheric controls on Eurasian snow extent. Int J Climatol 19:27-40

Cohen J (1994) Snow cover and climate. Weather 49:150-156

Cohen J, Entekhabi D (2001) Evolution of atmospheric response to early-season Eurasian snow cover anomalies. Mon Weather Rev 129:2746-2760

Gao R, Wei Z, Dong W, Wang C, Zhong H (2003) Variation of the snow and frozen soil over Qinghai-Xizhang Plateau in the late 20th century and their relations to climatic change. Plateau Meteorol 22(2):191-196 (in Chinese)

Groisman PY, Karl TR, Knight RW (1994a) Observed impact of snow cover on the heat balance and the rise of continental spring temperatures. Science 263:198-200

Groisman PY, Karl TR, Knight RW, Stenchikov GL (1994b) Changes of snow cover, temperature, and radiative heat balance over the Northern Hemisphere. J Clim 7 : 1633-1656

Hahn DG, Shukla J (1976) An apparent relationship between Eurasian snow cover and Indian monsoon rainfall. J Atmos Sci 33:2461-2462

IPCC (2001) Climate change 2001: impacts, adaption, and vulnerability. Report of Working Group II of the Intergovernmental Panel on Climate Change. Cambridge University Press, Cambridge

Kripalani RH, Kulkarni A (1999) Climatology and variability of historical Soviet snow depth data: some new perspectives in snow-Indian monsoon teleconnections. Clim Dyn 15:475-489

Leathers DJ, Robinson DA (1993) The association between extremes in North American snow cover extent and United States temperature. J Clim 6:1345-1355

Li C, Mu M (2001) The dipole in the Equatorial Indian Ocean and its impacts on climate. Chin J Atmos Sci 25(4): 433-443

Li C, Yanai M (1996) The onset and international variability of the Asian summer monsoon in relation to land-sea thermal contrast. J Clim 9:358-375

Li C, Mu M, Pan J (2002) Indian Ocean temperature dipole and SSTA in the equatorial Pacific Ocean. Chin Sci Bull 47(3):236-239

Li P (1989) Recent trends and regional differentiation of snow variation in China. In: Colbech SC (ed) Snow cover and glacier variations. IAHS Publ No. 183, IAHS Press, Wallingford, p 3-10

Parthasarathy B, Yang S (1995) Relationships between regional Indian summer monsoon rainfall and Eurasian snow cover. Adv Atmos Sci 12:143-150

Saji NH, Goswami BN, Vinayachandran PN, Yamagata T (1999) A dipole mode in the tropical Indian Ocean. Nature 401:360-363 
Serreze MC, Walsh JE, Chapin FS III, Osterkamp T and 6 others (2000) Observational evidence of recent change in the northern high-latitude environment. Clim Change 46: 159-207

Vernekar AD, Zhou J, Shukla JS (1995) The effect of Eurasian snow cover on the Indian monsoon. J Clim 8(2):248-266

Webster PT, Moore AM, Loschning JP, Leben RR (1999) Coupled ocean-atmosphere dynamics in the Indian Ocean during 1997-1998. Nature 401:356-360

Yang Q (1997) The coupled oscillations of $500 \mathrm{hPa}$ circulation, snow cover in Eurasia, and rainfall in China, on the time scale of 3-4 years. Clim Environ Res 2(4):347-355 (in Chinese)

Yang S (1993) ENSO-snow-monsoon associations and sea-

Editorial responsibility: Madhav L. Khandekar,

Unionville, Ontario, Canada sonal prediction. Proc 4th Symp Global Change Studies, Anaheim, CA. American Meteorological Society, Boston, MA, p 418-422

Yasunari T, Kitoh A, Tokioka T (1991) Local and remote response to excessive snow mass over Eurasia appearing in the northern spring and summer climate - a study with the MRI-GCM. J Meteorol Soc Jpn 69:473-487

Yin Y, Shi L, Ni Y (2001) A diagnosis of interactions between the tropical Indian Ocean and Pacific Ocean air-sea systems in the past 20 years. Chin J Atmos Sci 25(3):355-371

Zhang Y, Li T, Wang B (2003) Decadal change of snow depth over the Tibetan Plateau in spring: the associated circulation and its relationship to the East Asian summer monsoon rainfall. J Clim 17(14):2780-2793

Submitted: June 26, 2005; Accepted: November 3, 2005

Proofs received from author(s): December 7, 2005 